\title{
Mathematical Modeling of the Mechanical Characteristic of the Activated PTFE-Matrix Using the Method of Planning the Experiment
}

\author{
Bilous O. A. ${ }^{1}$, Hovorun T. P. ${ }^{1}$, Berladir K. V. ${ }^{1 *}$, Vorobiov S. I. ${ }^{2}$, Simkulet V. V. ${ }^{3}$ \\ ${ }^{1}$ Sumy State University, 2 Rymskogo-Korsakova St., 40007, Sumy, Ukraine; \\ ${ }^{2}$ Institute of Physics, P. J. Šafárik University in Košice, 2 Šrobárova St., 041 54, Košice, Slovakia; \\ ${ }^{3}$ Technical University of Košice, 1 Bayerova St., 080 01, Prešov, Slovakia
}

Article info:

Paper received:

The final version of the paper received:

Paper accepted online:
December 20, 2017

April 30, 2018

May 5, 2018
*Corresponding Author's Address:

kr.berladir@pmtkm.sumdu.edu.ua

\begin{abstract}
In this paper, the influence of the parameters of the technological process of mechanical activation on the physical characteristics of the polytetrafluoroethylene (PTFE) matrix is investigated. The paper presents a mathematical model of the dependence of breaking strength on the time of activation and rotating speed of working organs of a mill. Mathematical modeling is performed by the method of orthogonal experiment planning. The result of the study was a mathematical relation that explains the connection between the technical characteristics of the process of manufacturing a fluoroplastic composite and the mechanical characteristics of the material.

The statistical analysis of the experimental results is performed and the adequacy of the mathematical relations obtained is estimated. On the basis of the analysis of the obtained data, it can be concluded that the theoretical model obtained is adequate and suitable for performing the corresponding technological calculations. On the basis of the performed calculations, the conclusion is reached on the optimal technological mode of preparing the PTFE-matrix. The analysis shows that theoretical calculations confirm the experimental value of technological indicators under optimal operating conditions of the mill. Thus, the obtained dependence of breaking strength from the technological parameters of the activation process can be embedded in the algorithm for selecting the technological mode that ensures the output of products with specified quality indicators.
\end{abstract}

Keywords: polytetrafluoroethylene matrix, mechanical activation, mathematical modeling, breaking strength, parameters.

\section{Introduction}

Modern polymers and composite materials based on them are widely used in engineering as compositions exceeding in some of their characteristics structural steels and alloys [1-4]. A characteristic feature of these materials is the dependence of their mechanical characteristics on the conditions and modes of production of such structures. The question of determining the optimal parameters of the technological process for fabrication of fluoroplastic composites remains a topical issue [5-6].

The basis of any scientific approach for the optimization of technological processes is the application of methods of mathematical modelling with subsequent use of the obtained models for analysis of the influence of the main technological factors and the calculation of the optimal conditions for the performance of the technological process.

\section{Literature Review}

As shown by the practice of polymer material science [7-8], the physical, mechanical and tribotechnical properties of polymer composite materials (PCM) based on polytetrafluoroethylene (PTFE) are equally dependent on individual modes of technological production operations and on their combination (interaction).

The most acceptable in the case of PCM with a PTFE matrix is the technology of the energy effect on its structure and properties by mechanical activation [8].

A mathematical model of viscoelasticity of polymers was proposed in [9], combining the minimum number of possible parameters and a high degree of reliability in predicting of deformation processes. On the basis of the calculated deformation characteristics of polymers, deformation processes in the material were predicted. A 
criterion for the optimality of the choice of such a mathematical model is formulated.

In [10], using the linear differential equations of elastic deformation of a thin-walled cylindrical shell of variable thickness, an elastically deformed state of the fluoroplastic part was investigated. A calculation method for determining the value of the contact loading on the fluoroplastic element was developed. Recommendations to the designer of products from polytetrafluoroethylene at the stage of preliminary design of the unit are offered.

In [11] a simplified approach to the quasilinear viscoelastic modeling of PCM is formulated. It is based on a new principle of inclusion of nonlinearity and requires considerably fewer calculations when used in comparison with existing theories.

At the same time, the question of the influence of the parameters of the technological production process on the mechanical characteristics of the obtained PTFEcomposite remains little studied.

The aim of the paper is to study the results of the mechanical activation of PTFE by mathematical modeling and optimization

\section{Research Methodology}

Planning the experiment allows you to vary simultaneously all the factors (parameters) of the technological process and obtain quantitative estimates of both the main factors and the effects of interaction between them.

As a research material was chosen polytetrafluoroethylene grade F-4 “O” (GOST 10007-80).

Testing for breaking strength was carried out on the ring samples $\varnothing 50 \times \varnothing 40$, height $10 \mathrm{~mm}$, using rigid semidisks in accordance with GOST 25.603-82 at the tensile machine MP-05-1 at the rate of movement of grippers 10 $\mathrm{mm} / \mathrm{min}$ and the load of $100 \mathrm{kgf}$. Density $\rho\left(\mathrm{kg} / \mathrm{m}^{3}\right)$ of the samples was determined by the method of hydrostatic weighing in accordance with GOST 15139-69.

The influence of the features of the technological regimes of mechanical activation on the properties of the composite material was investigated on a high-speed mill МРП-1M with a maximum loading of $100 \mathrm{~g} / \mathrm{min}$. and a power of $1 \mathrm{~kW}$.

To determine the regularities of the results of the technological process, the initial plan of the full factor experiment (FFE) type $2^{2}$ was chosen. Investigation of the dependence of the strength characteristics of the matrix on the parameters of the activation process was performed by the method of orthogonal experimental design [12].

\section{Results and Discussion}

In studying this issue, as an optimization criterion (response function) was chosen the mechanical characteristic of fluoroplastic material - breaking strength $\left(\sigma_{b}, \mathrm{MPa}\right)$. The dominant factors were:

- $\mathrm{X}_{1}-$ rotating speed of working organs of a mill $\left(n, \min ^{-1}\right)$

- $\mathrm{X}_{2}$ - the time of activation $(\tau, \mathrm{min})$.
The task was solved with the help of two-factor regression analysis, as a result of which the optimal levels of the main factors and their interactions were determined.

The solution of the overall task of the study was divided into several stages:

- calculating the line average of the response function and the variance of the response at each point in the experiment plan;

- checking the homogeneity of line-by-line variances;

- determination of the coefficients of the mathematical model;

- determination of variance of reproducibility;

- the estimation of the statistical significance of the coefficients of the model;

- analysis of the adequacy of the model and experimental data, forming conclusions about the possibility of applying the developed model;

- determination of optimal parameters optimization of mechanical activation using one of the optimization methods.

For a two-factor experiment, the regression equation was considered as a complete quadratic polynomial of the form:

$$
y=b_{0} x_{0}+b_{1} x+b_{2} x_{2}+b_{12} x_{1} x_{2}+b_{11} x_{1}^{2}+b_{22} x_{2}^{2} .
$$

where $b_{i}$ - the coefficient of regression; $x_{0}-$ a fictitious variable; $\mathrm{y}$ - the optimization parameter.

In order to reduce the number of experiments, a composite (sequential) plan was used [12].

The total number of experiments was calculated by the formula [13]:

$$
N=N_{0}+2 k+n_{0} .
$$

The length of the "star shoulder" $\alpha$ was determined from the relation:

$$
\alpha=\sqrt{\frac{\sqrt{N_{0} N}-N_{0}}{2}} .
$$

Table 1 shows the parameters of the experiment planning.

Table 1 - Planning an experiment

\begin{tabular}{|c|c|}
\hline Parameters of the plan & FFE type $2^{2}$ \\
\hline The number of experiments in the matrix $\left(\mathrm{N}_{0}\right)$ & 4 \\
\hline The number of star points $(2 \mathrm{k})$ & 4 \\
\hline Number of zero points $\left(\mathrm{n}_{0}\right)$ & 1 \\
\hline Star shoulder & 1 \\
\hline
\end{tabular}

Factor space region shown in Table 2. The upper and lower levels were established experimentally during preliminary single-factor experiments. 
Table 2 - The factor variation matrix

\begin{tabular}{|c|c|c|c|}
\hline \multirow{2}{*}{ Levels and intervals of variation } & \multirow{2}{*}{ Code value } & $X_{1}$ & $X_{2}$ \\
\cline { 3 - 4 } & & 9000 & 7 \\
\hline Upper level & +1 & 7000 & 5 \\
\hline Zero level & 0 & 5000 & 3 \\
\hline Lower level & -1 & 2000 & 2 \\
\hline Variation interval & $\varepsilon$ &
\end{tabular}

Based on the values of these parameters, the centre of the plan and the variation step were determined. In the dimensionless coordinate system, the upper level was expressed as (+1), the lower level $(-1)$, the coordinates of the centre of the plan were equated to zero.

On the basis of the composed experimental planning matrix, a number of experiments were performed, the results of which made it possible to determine the coefficients of the corresponding dependence. To eliminate errors, randomization of experiments in time was used.

The result of the simulation was the ratio (4) in the coded values of the factors.

$$
\begin{gathered}
y=22,943+2,217 X_{1}+2,167 X_{2}-2,175 X_{1} X_{2}+ \\
+0,8435 X_{1}^{2}-7,9065 X_{2}^{2}
\end{gathered}
$$

For convenience of practical use of the obtained dependence by means of the encoding formulas by the reverse transition to natural variables, equation (5) is obtained in the natural values of the factors.

$$
\sigma_{b}(n, \tau)=-48,348+0,000875 \cdot n+24,656 \cdot \tau-
$$$$
-0,00054375 \cdot n \cdot \tau+0,0000002109 \cdot n^{2}-1,976625 \cdot \tau^{2} .
$$

In work the verification of the results of experiments on homogeneity was carried out, the significance of the model coefficients was investigated, the hypothesis of the adequacy of the model obtained was considered and the model was analyzed for informativeness.

Some statistical results of this work are presented in

\begin{tabular}{|c|c|c|c|}
\hline \multicolumn{2}{|r|}{ Statistical Analysis Parameters } & Symbol & Value \\
\hline \multirow{7}{*}{$\begin{array}{c}\text { Checking the results } \\
\text { of experiments } \\
\text { on homogeneity }\end{array}$} & Dispersion of reproducibility & $S_{\{y\}}^{2}$ & 0,4616 \\
\hline & Standard deviation & $S_{\{y\}}$ & 4,1540 \\
\hline & Number of degrees of freedom for dispersion of reproducibility & $f$ & 4,0000 \\
\hline & The experimental value of the G-criterion & $G^{\text {exper }}$ & 0,2143 \\
\hline & The critical value of the G-criterion & $G$ & 0,3518 \\
\hline & Level of significance & $\alpha$ & 0,0500 \\
\hline & Homogeneity of data & \multicolumn{2}{|c|}{ homogeneous } \\
\hline \multirow{6}{*}{$\begin{array}{c}\text { Checking the hypothesis } \\
\text { of model adequacy }\end{array}$} & Dispersion of adequacy & $S_{a d}{ }^{2}$ & 1,8216 \\
\hline & The experimental value of the F- criterion & $F^{\text {exper }}$ & 3,9500 \\
\hline & The critical value of the F-criterion for adequacy & $F$ & 4,2800 \\
\hline & Number of degrees of freedom for adequacy & $f$ & 6,0000 \\
\hline & Level of significance & $\alpha$ & 0,0500 \\
\hline & Adequacy of the model & \multicolumn{2}{|c|}{ adequate } \\
\hline
\end{tabular}
Table 3.

Table 3 - Results of statistical analysis of the mathematical model

The model has excellent information properties, good computational stability and satisfactory describing properties. The mathematical relation was adopted for use, since it allows us to predict with sufficient accuracy the value of the mechanical characteristic with the corresponding parameters of the technological process.

Fig. 1 shows the response surface and the level lines of dependence of the breaking strength $\left(\sigma_{b}, \mathrm{MPa}\right)$ from rotating speed of working organs of a mill $\left(n, \min ^{-1}\right)$ and the time of activation of PTFE-matrix ( $\tau$, min). The dependence (5) was constructed using a graphical editor SIGMAPLOT 11.0.

Using the second-order regression equation allows us to determine the coordinates of the optimum point of the response function. To determine the coordinates of the extremum points, the partial derivatives for each of the values of the factors were found [13]. 


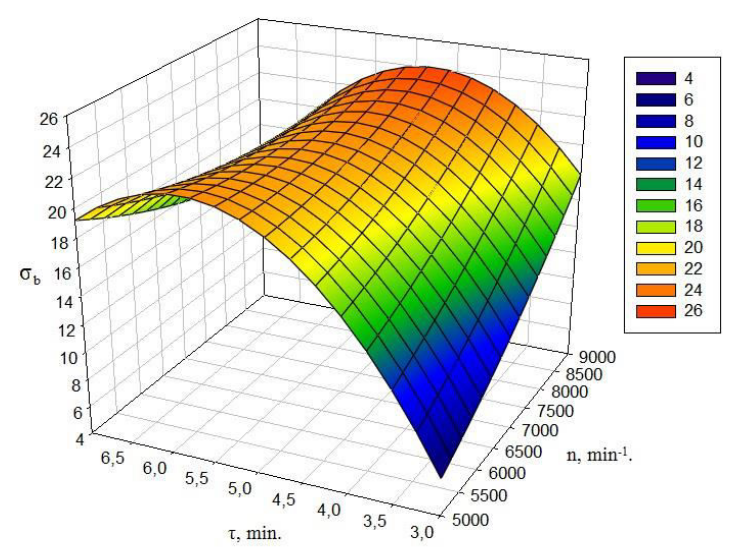

a

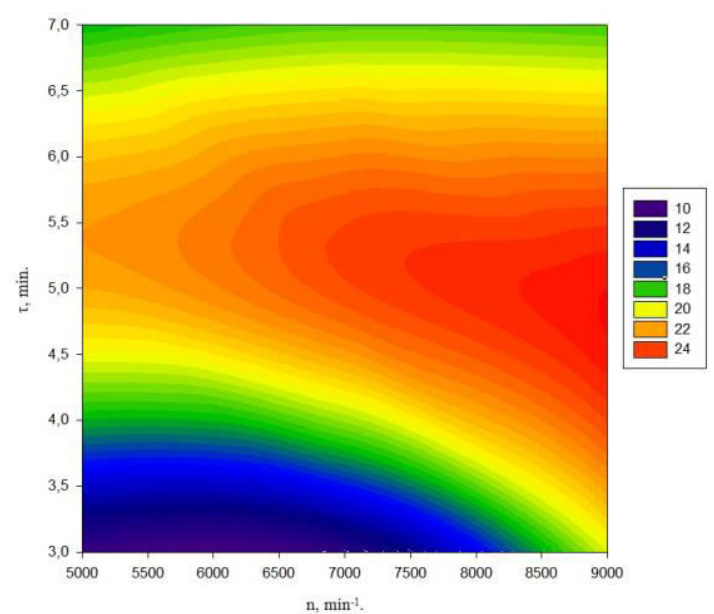

b

Figure 1 - The response surface (a) and the level lines (b) of dependence of the breaking strength $\left(\sigma_{b}, \mathrm{MPa}\right)$ of PTFE-matrix from rotating speed of working organs of a mill $\left(n, \mathrm{~min}^{-1}\right)$ and the time of activation of PTFE-matrix $(\tau$, min).

We considered a system of equations:

$$
\left\{\begin{array}{l}
\frac{\partial Y\left(X_{1} ; X_{2}\right)}{\partial X_{1}}=0 \\
\frac{\partial Y\left(X_{1} ; X_{2}\right)}{\partial X_{2}}=0
\end{array}\right.
$$

The solutions of the resulting system (6) of equations represent the coordinates of the extremum points of the function being studied for a given area of investigation.

Based on the optimization results, the theoretical value of the maximum breaking strength of the activated PTFEmatrix was calculated (Table 4).

The relative error in determining the breaking strength did not exceed $5 \%$, which indicates the reliability of the results of mathematical modeling.

Table 4 - Optimal modes of equipment operation during mechanical activation of the PTFE-matrix

\begin{tabular}{|c|c|c|}
\hline Parameter & Model & Experiment \\
\hline Breaking strength, MPa & 26,0035 & 24,8000 \\
\hline Rotating speed of working organs of a mill $\left(n, \mathrm{~min}^{-1}\right)$ & 9000 & 9000 \\
\hline Time of activation $(\tau, \mathrm{min})$ & 4,999 & 5,000 \\
\hline
\end{tabular}

\section{Conclusions}

As a result of the experiment, was obtained a twofactor mathematical model that allows predicting the strength characteristics of the PTFE-matrix and optimally design it depending on the indicators of the technological process.

Thus, the performed researches and the obtained dependences allow theoretically predict the breaking strength of the PTFE-matrix in dependence on the technological characteristics of the mechanical activation (the time of activation and rotating speed of working organs of a mill).

The conducted practical studies show that theoretical calculations confirm the experimental value under optimal operating conditions of a mill.

In addition, the obtained dependence of the value of breaking strength from the technological parameters of the activation process can be embedded in the algorithm for selecting the technological regime that ensures the output of products with given quality indicators, and at the same time achieving an extreme value of a certain efficiency criterion. 


\title{
References
}

1. Smith, D. W., Iacono, S. T., \& Iyer, S. S. (2014). Handbook of fluoropolymer science and technology. Hoboken, Wiley.

2. Negrov, D. A., Putintsev, V. Yu., Peredel'skaya, O. A., Naumova, A. V. (2015). Tekhnologiya izgotovleniya detaley uzlov treniya iz polimernykh kompozitsionnykh materialov. Bulletin of YuUrGU, series "Mashinostroyeniye", Vol. 15, Issue 2, 13-19 [in Russian].

3. Venkateswarlu, G., Sharada, R., \& Bhagvanth Rao M. (2014). Polytetrafluoroethylene (PTFE) based composites. Journal of Chemical and Pharmaceutical Research, Vol. 6, Issue 10, 508-517.

4. Budnik, O. A., Sviderskii, V. A., Budnik, A. F., Berladir, K. V., Rudenko, P. V. (2016). Composite material for chemical and petrochemical equipment friction assemblies. Chemical and Petroleum Engineering, Vol. 52, Issue 1, 63-68, doi: 10.1007/s10556-016-0149-x.

5. Jordan, J. L., Siviour, C. R., Foley, J. R., \& Brown, E. N. (2007). Compressive properties of extruded polytetrafluoroethylene. Polymer, Vol. 48, Issue 14, 4184-4195, doi: 10.1016/j.polymer.2007.05.038.

6. Struk, V. A., Tsvetnikov, A. K., Antonov, A. S., et al. (2009). Mekhanokhimicheskiye aspekty tekhnologii formirovaniya i primeneniya ftoroplastovykh kompozitov. Izvestiya NAN Belarusi, Vol. 3, 28 -35 [in Russian].

7. Mohd, F. O., Akil, H. M., \& Ahmad, Z. A. (2011). Measurement and prediction of compressive properties of polymers at high strain rate loading. Mater Des, Vol. 32, Issue 8-9, 4207-4215.

8. Budnik, O. A., Budnik, A. F., Sviderskiy, V. A., Berladir, K. V., \& Rudenko, P. V. (2016). Structural conformation of polytetrafluoroethylene composite material. Chemistry \& Chemical Technology, Vol. 10, No. 2, 241-246.

9. Bukhkalo, S. I., Ol'khovskaya, O. I., \& Borkhovich, A. A. (2008). Otsenka kachestva vtorichnykh polimerov s pomoshch'yu matematicheskoy modeli. Íntegrovani tekhnologiï ta yenergozberezhennya, Vol. 2, 51-55 [in Russian].

10. Shevchenko, S. A., Valivakhin, S. O., Hryhor'yev, O. L., \& Stepanov, M. S. (2016). Matematychna model' manzhetnykh ushchil'nen' iz ftoroplasta dlya ahrehativ pnevmoavtomatyky raketnykh dvyhuniv. Visnyk NTU «KHPI». Seriya: Matematychne modelyuvannya v tekhnitsi ta tekhnolohiyakh, Vol. 6, Issue 1178, 124-143 [in Ukrainian].

11. Nekouzadeh, A., Pryse, K. M., Elson, E. L., \& Genin, G. M. (2007). A simplified approach to quasi-linear viscoelastic modeling. Journal of Biomechanics, Vol. 40, Issue 14, 3070-3078, doi: 10.1016/j.jbiomech.2007.03.019.

12. Dreyper, N., \& Smit, G. (2007). Prikladnoy regressionnyy analiz. Moscow : Vil'yams [in Russian].

13. Meledina, T. V., \& Danina, M. M. (2015). Metody planirovaniya i obrabotki rezul'tatov nauchnykh issledovaniy. Saint Petersburg, NIU ITMO [in Russian].

\section{Математичне моделювання механічної характеристики активованої ПТФЕ-матриці на основі методу планування експерименту}

\author{
Білоус О. А. ${ }^{1}$, Говорун Т. П. ${ }^{1}$, Берладір Х. В. ${ }^{*}$, Воробйов С. I. ${ }^{2}$, Сімкулет В. В. ${ }^{3}$ \\ ${ }^{1}$ Сумський державний університет, вул. Римського-Корсакова, 2, 40007, м. Суми, Україна; \\ ${ }^{2}$ Інститут фізики, Університет ім. П. Й. Шафарика у м. Кошице, вул. Шробарова, 2, 041 54, м. Кошице, Словаччина; \\ ${ }^{3}$ Технічний університет м. Кошице, вул. Баєрова, 1, 080 01, м. Прешов, Словаччина
}

Анотація. Досліджено вплив параметрів технологічного процесу механічної активації на фізичні характеристики політетрафторетиленової (ПТФЕ) матриці.В роботі представлена математична модель залежності міцності при розриві від часу активації та числа обертів робочих органів подрібнювача. Математичне моделювання здійснюється методом ортогонального планування експерименту. Результатом дослідження є математичне співвідношення, яке пояснює зв'язок між технічними характеристиками процесу виготовлення фторопластового композиту та механічними характеристиками матеріалу.

Виконано статистичний аналіз результатів експерименту і проведено оцінку адекватності побудованих математичних співвідношень. На підставі аналізу даних зроблено висновок, що отримана теоретична модель адекватна та придатна для виконання відповідних технологічних розрахунків.На підставі проведених розрахунків зроблено висновок щодо оптимального технологічного режиму підготовки ПТФЕ-матриці. Аналізи показали, що теоретичні розрахунки підтверджують експериментальне значення при оптимальних режимах роботи подрібнювача.Таким чином, отримана залежність міцності при розриві від технологічних параметрів процесу активації може бути закладена в алгоритм вибору технологічного режиму, що забезпечує випуск продукції з заданими якісними показниками.

Ключові слова: політетрафторетиленова матриця, механічна активація, математичне моделювання, міцність при розриві, параметри. 